\title{
Effect of Dietary Dextrin Levels on the Growth and Feed Efficiency, the Chemical Composition of Liver and Dorsal Muscle, and the Absorption of Dietary Protein and Dextrin in Fishes*1
}

\author{
Masayuki FURUICHI ${ }^{* 2}$ and Yasuo YoNE*2 \\ (Received September 17, 1979)
}

\begin{abstract}
In order to investigate the utilization of carbohydrate by carp, Cyprinus carpio, red sea bream, Chrysophrys major, and yellow tail, Seriola quinqueradiata, the fishes were reared on diets containing $0 \%, 10 \%, 20 \%, 30 \%$ and $40 \%$ dextrin for 30 days. Growth retardation and low feed efficiency were noticed in carp fed on a $40 \%$ dextrin diet, red sea bream on $30 \%$ dextrin and yellow tail on $20 \%$ dextrin. The rates of the increase in liver glycogen and the decrease in liver and muscle lipid were lowest in carp. On the other hand, comparably high percent absorption of protein and dextrin was determined in all species regardless of dietary dextrin levels. From these findings, it is presumed that the low growth and feed efficiency resulting from feeding high dextrin diets might be caused by the poor capability of utilizing the absorbed dextrin, and that the capacity of carp is highest among the fish tested.
\end{abstract}

The aquaculture of fish is recently under development in various districts. However, the fishes are generally reared on high protein diets as compared to domestic animals. A considerable portion of dietary protein may possibly be utilized as the energy source. If the fishes could utilize a large amount of carbohydrate effectively, the expansion of its farming can be actualized. Many studies on the utilization of carbohydrate by fishes have separately been conducted by the use of different carbohydrate sources. ${ }^{1-171}$ Accordingly, in the present paper, the capability of several kinds of fishes with different digestive systems for utilizing carbohydrate was simultaneously studied by investigating the effect of dietary dextrin levels on the growth and feed efficiency of the fishes, the chemical composition of liver and dorsal muscle, and the percent absorption of dietary protein and dextrin. The fishes studied were carp, an omnivorous fish, red sea bream, a semi-carnivorous one, and yellow tail, an extremely carnivorous one.

\section{Materials and Methods}

\section{Fishes}

Young carp and red sea bream were used, which grew at a comparable rate during a 3-month prefeeding period with a compounded feed, and young yellow tail with jack mackerel for 2 weeks. Fish were equally divided into five groups in each species, based on the average body weight and the number of fish with comparable weight.

\section{Diets}

Five test diets containing $0,10,20,30$, and $40 \%$ dextrin were used. Dextrin used (Matsutani Chemical Industry Co., Ltd.; Pinedex $\# 2$ ) was produced by hydrolyzing potato starch with acid. The composition of the diets is shown in Table 1. The dietary calories were maintained at a certain level by decreasing the amount of casein, gelatin, and amino acid mixture with the increase of dextrin in the diets. The preparation of diets was conducted as presented in the previous paper. ${ }^{181}$

\section{Feeding Method}

Each lot of 63 carp and 45 red sea bream were maintained in an aquarium $(90 \times 45 \times 45 \mathrm{~cm})$, and each lot of 50 yellow tail in a concrete, round tank of 3 ton capacity (Diameter $2 \mathrm{~m} \times$ Depth $1 \mathrm{~m}$ ), and fed test diets for 30 days, respectively. Water temperature was approximately $23^{\circ} \mathrm{C}$ for carp and red sea bream, and within the range of

*1 Contribution from Fish. Res. Lab., Kyushu Univ., No. 143. The Utilization of Carbohydrate by FishesI. This work was supported in Part by Grant-in-Aid for Encouragement of Young Scientist (Grant No. 176129) from the Ministry of Education of Japan and was orally presented to the Spring Meeting of Japan. Soc. Sci. Fish. at Tokyo in April, 1978.

*2 Fish. Res. Lab., Kyushu Univ., Tsuyazaki, Fukuoka 811-33, Japan.（古市政幸・米 沗夫：九州大 学農学部附属水産実験所). 
Table 1. Composition of test diets

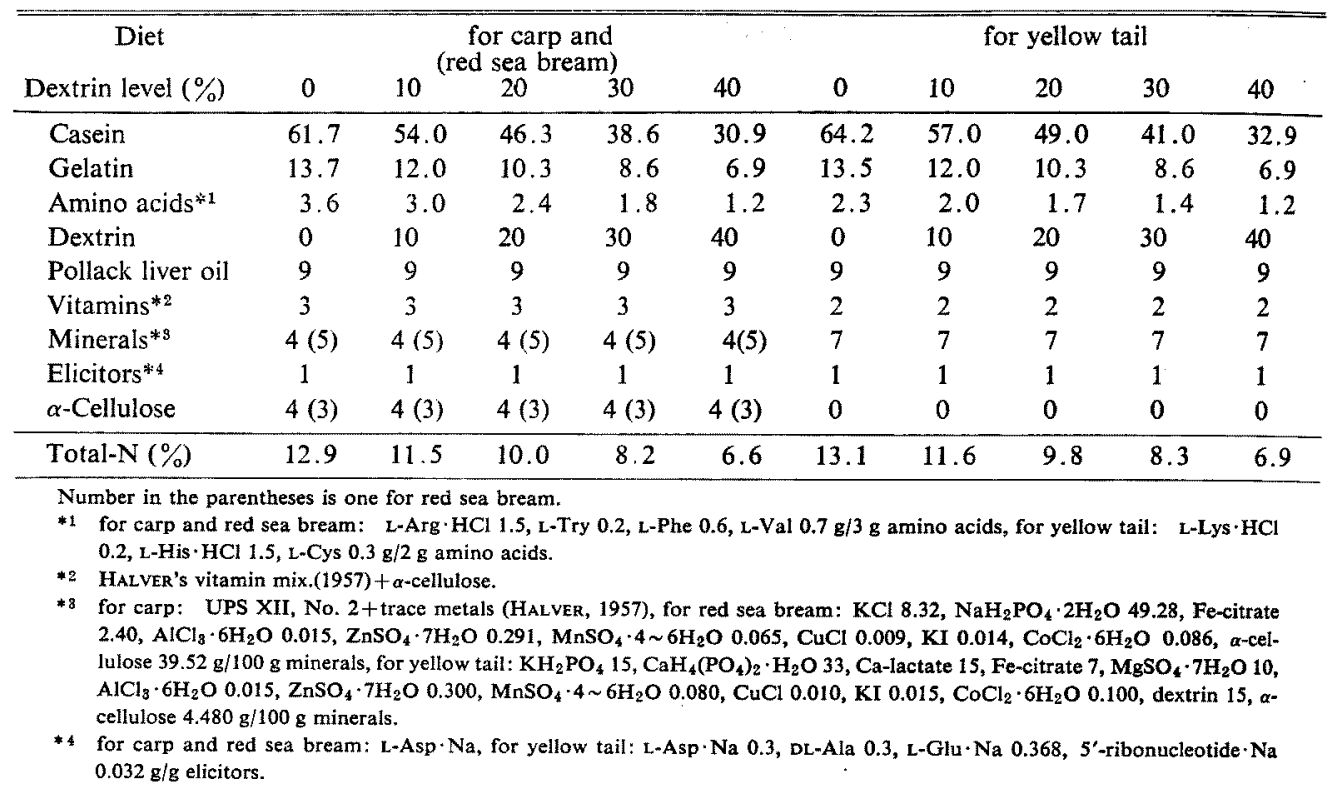

$20^{\circ} \mathrm{C}$ to $24.5^{\circ} \mathrm{C}$ for yellow tail during the feeding trial period, respectively. Fish care and feeding were achieved as described previously. ${ }^{18 !}$

\section{Weighing and Chemical Analysis of Fish}

Fish were individually weighed after anesthetization with quinaldine $(10 \mathrm{ppm})$ every 15 days. At the end of the feeding trial, 5 fish from each group were sampled at random. The homogenized liver and dorsal muscle which were taken from each fish in the same amount, were mixed separately for each group and subjected to the determination of the protein, lipid, and glycogen content. Protein and glycogen were quantified by the method of KJELDAHL and CARROLL et al ${ }^{19 !}$, respectively. Lipid was extracted with ethyl ether and the Soxhlet extractor.

\section{Determination of Percent Absorption}

After the feeding trial, the percent absorption of dietary protein and dextrin was estimated by the indirect method using $\mathrm{Cr}_{2} \mathrm{O}_{3}$ as an indicater. Namely, after a 3-day feeding period with the test diets containing $1 \% \mathrm{Cr}_{2} \mathrm{O}_{3}$, the feces was collected by applying slight pressure on the ventral side of the fish at 7 hours after the final feeding. The contents of $\mathrm{Cr}_{2} \mathrm{O}_{3}$ and protein in the diet and feces were quantified by the method of FuRUKawa and TSUKAHARA ${ }^{201}$ and of KJELDAHL, respectively. The carbohydrate contents of the diet and feces were determined by the phenol-sulfuric acid me- thod ${ }^{211}$ after hydrolysis with $\mathrm{HCl}$.

\section{Results and Discussion}

\section{Growth and Feed Efficiency}

The carp exhibited growth retardation and remarkably low feed efficiency when the fish were fed the diet containing a $40 \%$ level of dextrin as shown in Table 2. However, no significant difference was detected between the $40 \%$ dextrin group and the dextrin-free diet group in the average body weight at the 30th day. In case of red sea bream and yellow tail, the growth and feed efficiency of the fishes decreased with the increase of dietary dextrin level, except in the $10 \%$ dextrin group of red sea bream (Tables 3 and 4). At the end of the feeding trial, the average body weight of red sea bream fed the diet with $30 \%$ or $40 \%$ dextrin and of yellow tail with dextrin at levels higher than $20 \%$ was significantly lower when compared to the control group without dextrin, respectively. The results indicate that the optimum level of dietary dextrin for the maximum growth and feed efficiency of the fishes differs between the species, and was lower than that of domestic animals.

Proximate Composition of Liver and Dorsal Muscle As shown in Tables 5, 6, and 7, the liver glycogen increased, and the liver and muscle lipid de- 
Table 2. Effect of dietary dextrin levels on growth and feed efficiency of carp

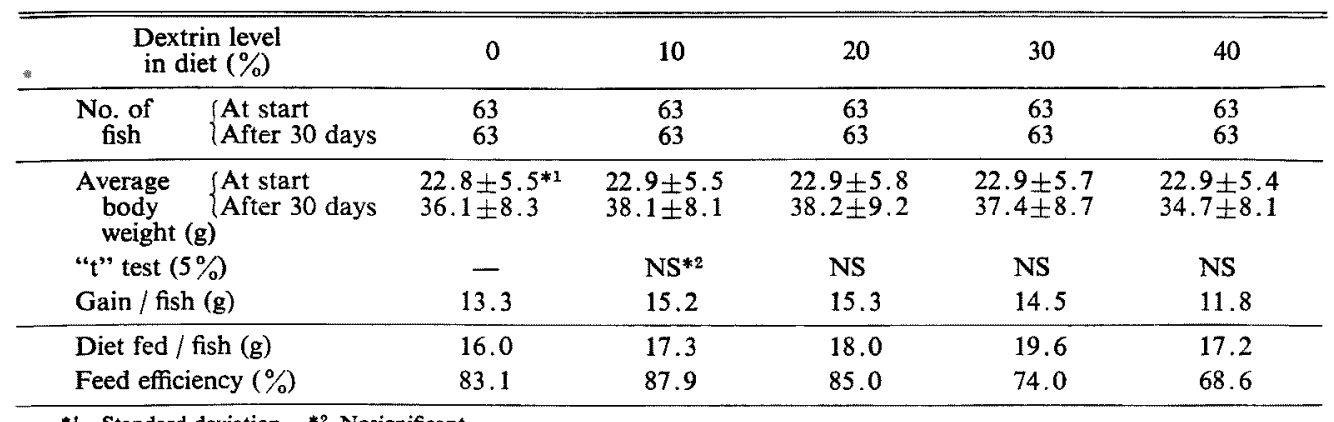

*1 Standard deviation. *2 Nosignificant.

Table 3. Effect of dietary dextrin levels on growth and feed efficiency of red sea bream

\begin{tabular}{|c|c|c|c|c|c|c|}
\hline \multicolumn{2}{|c|}{$\begin{array}{l}\text { Dextrin level } \\
\text { in diet }(\%)\end{array}$} & \multirow{2}{*}{$\begin{array}{c}0 \\
45 \\
41 \\
\end{array}$} & \multirow{2}{*}{$\begin{array}{c}10 \\
45 \\
45 \\
\end{array}$} & \multirow{2}{*}{$\begin{array}{r}20 \\
45 \\
43 \\
\end{array}$} & \multirow{2}{*}{$\begin{array}{r}30 \\
45 \\
43 \\
\end{array}$} & \multirow{2}{*}{$\begin{array}{c}40 \\
45 \\
43\end{array}$} \\
\hline $\begin{array}{l}\text { No. of } \\
\text { fish }\end{array}$ & $\left\{\begin{array}{l}\text { At start } \\
\text { After } 30 \text { days }\end{array}\right.$ & & & & & \\
\hline $\begin{array}{l}\text { Average } \\
\text { body } \\
\text { weight }\end{array}$ & $\left\{\begin{array}{l}\text { At start } \\
\text { After } 30 \text { days }\end{array}\right.$ & $\begin{array}{l}33.4 \pm 2.9 \\
47.2 \pm 6.7\end{array}$ & $\begin{array}{l}33.5 \pm 2.8 \\
47.7 \pm 7.5\end{array}$ & $\begin{array}{l}33.4 \pm 2.8 \\
46.2 \pm 9.6\end{array}$ & $\begin{array}{l}33.4 \pm 2.7 \\
43.9 \pm 7.9\end{array}$ & $\begin{array}{l}33.5 \pm 2.7 \\
42.8 \pm 5.8\end{array}$ \\
\hline \multicolumn{2}{|c|}{ "t" test $(5 \%)$} & - & NS & NS & $\mathrm{S}^{* 1}$ & $\mathbf{S}$ \\
\hline \multicolumn{2}{|c|}{ Gain / fish (g) } & 13.8 & 14.2 & 12.8 & 10.5 & 9.3 \\
\hline \multirow{2}{*}{\multicolumn{2}{|c|}{$\begin{array}{l}\text { Diet fed / fish (g) } \\
\text { Feed efficiency }(\%)\end{array}$}} & 18.8 & 18.0 & 21.3 & 21.3 & 20.6 \\
\hline & & 73.4 & 78.9 & 60.1 & 49.3 & 45.1 \\
\hline
\end{tabular}

Table 4. Effect of dietary dextrin levels on growth and feed efficiency of yellow tail

\begin{tabular}{|c|c|c|c|c|c|c|}
\hline \multicolumn{2}{|c|}{$\begin{array}{l}\text { Dextrin level } \\
\text { in diet }(\%)\end{array}$} & \multirow{2}{*}{$\begin{array}{r}0 \\
50 \\
43 \\
\end{array}$} & \multirow{2}{*}{$\begin{array}{l}10 \\
50 \\
44 \\
\end{array}$} & \multirow{2}{*}{$\begin{array}{l}20 \\
50 \\
46 \\
\end{array}$} & \multirow{2}{*}{$\begin{array}{l}30 \\
50 \\
42\end{array}$} & \multirow{2}{*}{$\begin{array}{l}40 \\
50 \\
41\end{array}$} \\
\hline $\begin{array}{l}\text { No. of } \\
\text { fish }\end{array}$ & $\left\{\begin{array}{l}\text { At start } \\
\text { After } 30 \text { days }\end{array}\right.$ & & & & & \\
\hline $\begin{array}{l}\text { Average } \\
\text { body } \\
\text { weight }\end{array}$ & $\left\{\begin{array}{l}\text { At start } \\
\text { After } 30 \text { days }\end{array}\right.$ & $\begin{array}{l}20.8 \pm 3.2 \\
87.6 \pm 17.6\end{array}$ & $\begin{array}{l}21.0 \pm 3.3 \\
81.0 \pm 16.9\end{array}$ & $\begin{array}{l}20.8 \pm 3.1 \\
76.7 \pm 19.6\end{array}$ & $\begin{array}{l}20.9 \pm 3.3 \\
62.3 \pm 15.9\end{array}$ & $\begin{array}{l}20.9 \pm 3.1 \\
44.3 \pm 14.1\end{array}$ \\
\hline \multicolumn{2}{|c|}{ "t" test $(5 \%)$} & 一 & NS & $\mathrm{S}$ & $\mathbf{S}$ & $\mathbf{S}$ \\
\hline \multicolumn{2}{|c|}{ Gain / fish (g) } & 66.8 & 60.0 & 55.9 & 41.4 & 23.4 \\
\hline \multicolumn{2}{|c|}{ Diet fed / fish (g) } & 55.8 & 55.2 & 58.7 & 60.5 & 60.6 \\
\hline \multicolumn{2}{|c|}{ Feed efficiency $(\%)$} & 119.7 & 108.7 & 95.2 & 68.4 & 38.6 \\
\hline
\end{tabular}

creased in all species fed the dextrin containing diets. The rates of the increase in glycogen and the decrease in lipid were lowest in carp.

Percent Absorption of Dietary Protein and Dextrin

The fishes fed diets with and without dextrin showed comparably high percent absorption of dietary protein and dextrin (Table $8(\mathrm{a})$ ). In order to confirm this result, the percent absorption was redetermined using other carp and red sea bream fed the same diets as listed in Table 1 for 7 days. Consequently, a high percent absorption of protein and dextrin similarly to the values in Table 8 (a) was recognized in both carp and red sea bream, as shown in Table 8 (b).

From these findings, it can be considered that the growth retardation and decreased feed efficiency resulting from the feeding of diets with a high level of dextrin were due to the low utilization of dextrin absorbed, and that carp can utilize dietary dextrin more effectively than red sea bream and yellow tail.

In the previous study with red sea bream by the 
Table 5. Effect of dietary dextrin levels on proximate composition of liver and dorsal muscle of carp

\begin{tabular}{lccccc}
\hline \hline $\begin{array}{c}\text { Dextrin level } \\
\text { in diet (\%) }\end{array}$ & 0 & 10 & 20 & 30 & 40 \\
\hline Liver & & & & & \\
Hepatosomatic index*1 & $2.28 \pm 0.55$ & $2.48 \pm 0.22$ & $2.20 \pm 0.35$ & $2.32 \pm 0.44$ & $2.37 \pm 0.38$ \\
"t" test (5\%) & - & $\mathrm{NS}$ & $\mathrm{NS}$ & $\mathrm{NS}$ & $\mathrm{NS}$ \\
Moisture (\%) & 64.5 & 69.7 & 71.5 & 70.5 & 66.8 \\
Protein (\% d.m.)*2 & 50.4 & 49.4 & 50.0 & 50.2 & 47.3 \\
Lipid (\% d.m.) & 40.8 & 34.5 & 35.4 & 35.1 & 38.4 \\
Glycogen (\% d.m.) & 5.2 & 7.6 & 9.9 & 8.3 & 8.7 \\
\hline Muscle & & & & & 77.6 \\
Moisture (\%) & 77.6 & 77.2 & 77.5 & 77.6 & 7.5 \\
Protein (\% d.m.) & 88.4 & 88.6 & 90.2 & 88.4 & 7.2 \\
Lipid (\% d.m.) & 8.3 & 6.6 & 5.4 & 7.5 & 0.001 \\
Glycogen (\% d.m.) & 0.001 & 0.001 & 0.001 & 0.001 & \\
\hline
\end{tabular}

*1 Liver weight $(\mathrm{g}) \times 100 /$ Body weight $(\mathrm{g})$.

*2\% dry matter.

Table 6. Effect of dietary dextrin levels on proximate composition of liver and dorsal muscle of red sea bream

\begin{tabular}{lccccc}
\hline \hline $\begin{array}{c}\text { Dextrin level } \\
\text { in diet (\%) }\end{array}$ & 0 & 10 & 20 & 30 & 40 \\
\hline Liver & & & & & \\
Hepatosomatic index & $1.66 \pm 0.30$ & $1.82 \pm 0.48$ & $1.99 \pm 0.47$ & $1.90 \pm 0.41$ & $1.76 \pm 0.35$ \\
"t" test (5\%) & - & NS & NS & NS & NS \\
Moisture (\%) & 65.4 & 67.8 & 68.0 & 69.4 & 66.2 \\
Protein (\% d.m.) & 50.5 & 56.6 & 41.7 & 45.9 & 43.4 \\
Lipid (\% d.m.) & 36.7 & 28.6 & 29.4 & 21.2 & 28.7 \\
Glycogen (\% d.m.) & 8.4 & 11.1 & 27.3 & 26.6 & 23.9 \\
\hline Muscle & & & & & 77.2 \\
Moisture (\%) & 76.4 & 76.8 & 76.4 & 76.7 & 89.8 \\
Protein (\% d.m.) & 88.2 & 90.1 & 90.7 & 89.4 & 3.9 \\
Lipid (\% d.m.) & 6.8 & 5.2 & 5.4 & 4.8 & 0.002 \\
Glycogen (\% d.m.) & 0.002 & 0.001 & 0.002 & 0.001 & \\
\hline
\end{tabular}

Table 7. Effect of dietary dextrin levels on proximate composition of liver and dorsal muscle of yellow tail

\begin{tabular}{|c|c|c|c|c|c|}
\hline $\begin{array}{c}\text { Dextrin level } \\
\text { in diet }(\%)\end{array}$ & 0 & 10 & 20 & 30 & 40 \\
\hline \multicolumn{6}{|l|}{ Liver } \\
\hline Hepatosomatic index & $1.51 \pm 0.28$ & $1.55 \pm 0.21$ & $1.45 \pm 0.32$ & $1.33 \pm 0.28$ & $1.33 \pm 0.41$ \\
\hline "t $t "$ test $(5 \%)$ & - & NS & NS & NS & NS \\
\hline Moisture $(\%)$ & 76.5 & 76.2 & 76.4 & 76.3 & 77.8 \\
\hline Protein (\% d.m.) & 76.2 & 76.1 & 74.6 & 70.9 & 72.5 \\
\hline Lipid (\% d.m.) & 20.4 & 17.6 & 16.9 & 16.5 & 13.5 \\
\hline Glycogen (\% d.m.) & 0.9 & 2.2 & 3.5 & 7.0 & 8.6 \\
\hline \multicolumn{6}{|l|}{ Muscle } \\
\hline Moisture (\%) & 76.4 & 75.7 & 76.9 & 76.8 & 77.4 \\
\hline Protein (\% d.m.) & 88.6 & 88.1 & 93.5 & 94.0 & 93.4 \\
\hline Lipid (\% d.m.) & 8.9 & 4.9 & 4.8 & 4.7 & 4.4 \\
\hline Glycogen (\% d.m.) & 0.018 & 0.028 & 0.020 & 0.016 & 0.019 \\
\hline
\end{tabular}


Table 8. Effect of dietary dextrin levels on percent absorption of protein and dextrin by fishes (a) After 30 days feeding

\begin{tabular}{ccccccc}
\hline \multicolumn{2}{c}{$\begin{array}{c}\text { Dextrin level } \\
\text { in diet }(\%)\end{array}$} & 0 & 10 & 20 & 30 & 40 \\
\hline Carp & Protein & 92.7 & 93.6 & 90.3 & 91.0 & 90.6 \\
& Dextrin & - & 98.7 & 98.5 & 97.3 & 97.6 \\
\hline Red sea & Protein & 98.1 & 98.3 & 98.6 & 95.8 & 96.4 \\
bream & Dextrin & - & 96.8 & 92.4 & 92.6 & 92.3 \\
\hline Yellow & Protein & 98.5 & 98.9 & 98.8 & 98.1 & 98.4 \\
tail & Dextrin & - & 97.4 & 95.9 & 95.3 & 93.1 \\
\hline
\end{tabular}

(b) After 7 days feeding

\begin{tabular}{rcccccc}
\hline \hline \multicolumn{2}{c}{$\begin{array}{c}\text { Dextrin level } \\
\text { in diet (\%) }\end{array}$} & 0 & 10 & 20 & 30 & 40 \\
\hline Carp & Protein & 93.0 & 93.8 & 94.7 & 94.1 & 92.4 \\
& Dextrin & - & 99.7 & 99.4 & 99.5 & 99.4 \\
\hline Red sea & Protein & 99.2 & 99.2 & 99.0 & 99.1 & 98.6 \\
bream & Dextrin & - & 98.9 & 95.9 & 96.0 & 94.6 \\
\hline
\end{tabular}

use of crude diets containing white fish meal and glucose etc., the percent absorption of protein and glucose declined with the increase of dietary glucose level. ${ }^{17}$ Therefore, we supposed that the decreased absorption is a cause for the low growth and feed efficiency which resulted from feeding a high glucose diet. In the present study, however, a decrease in absorption was not recognized in the duplicate tests. The reason of this discrepancy is unknown.

\section{References}

1) A. M. Phillirs and D. R. Brockway: Prog. Fish-Cult., 18, 113-116 (1956).

2) A. M. Phillips, JR.: Prog. Fish-Cult., 23, 66-69 (1961).

3) D. R. BuHler and J. E. Halver: J. Nutr., 74, 307-318 (1961).

4) A. M. Phillips, JR., D. L. Livingston, and H. A. Poston: Fish. Res. Bull., No. 29, 6-14 (1966).

5) T. NOSE: Bull. Freshwater Fish. Res. Lab., 21, 85-98 (1971).

6) T. Nose and S. ARAI: Bull. Freshwater Fish. Res. Lab., 22, 145-155 (1972).

7) M. NAGAI and S. IKedA: Bull. Japan. Soc. Sci. Fish., 37, 404-409 (1971).

8) M. NAGAI and S. IKEDA: Bull. Japan. Soc. Sci. Fish., 37, 410-414 (1971).

9) M. NAGAI and S. IKedA: Bull. Japan. Soc. Sci.
Fish., 38, 137-143 (1972).

10) M. NAgAi and S. Ikeda: Bull. Japan. Soc. Sci. Fish., 39, 633-643 (1973).

11) C. Ogino, J. Y. ChIOU, and T. Takeuchi: Bull. Japan. Soc. Sci. Fish., 42, 213-218 (1976).

12) T. Sato, M. Kawanishi, and C. Kitazima: Bull. Hiroshima Fish. Exp. Stn., 29, 66-81 (1968).

13) S. SHmeno: Rep. Fish. Lab., Kochi Univ., No. 2, 1-107 (1974).

14) S. Shimeno, H. Hosokawa, H. Hirata, and M. TAKEDA; Bull. Japan. Soc. Sci. Fish., 43, 213217 (1977).

15) S. Shimeno, H. Hosokawa, H. Kaziyama, and M. TAKeda: Rep. Fish. Lab., Kochi Univ., No. 3, 89-99 (1978).

16) M. Furuichi and Y. YONE: Rep. Fish. Res. Lab., Kyushu Univ., No. 1, 75-81 (1971).

17) M. Furuichi, K. Shitanda, and Y. Yone: Rep. Fish. Res. Lab., Kyushu Univ., No. 1, 91-100 (1971).

18) Y. Yone, S. Sakamoto, and M. Furuichi: Rep. Fish. Res. Lab., Kyushu Univ., No. 2, 13-24 (1974).

19) N. V. Carroll, R. W. Longley, and J. H. RoE: J. Biol. Chem., 220, 583-593 (1956).

20) A. Furukawa and H. Tsukahara: Bull. Japan. Soc. Sci. Fish., 32, 502-506 (1966).

21) J. E. Hodge and B. T. Hofreiter: in "Method in Carbohydrate Chemistry" (ed. by R. L. WHISTLER and M. L. Wolfrom), Vol. 1, Academic Press, New York, 1962, pp. 388-389. 